\title{
Lean in Construction in Bosnia and Herzegovina
}

\author{
Anamarija Arapović \\ M.Eng.C.E. \\ anamarija.arapovic@gf.sum.ba \\ Ivana Domljan \\ University of Mostar, Faculty of Civil Engineering, prof. Ph.D \\ ivana.domljan@gf.sum.ba \\ Dragan Katić \\ University of Mostar, Faculty of Civil Engineering, M.Sc. \\ dragan.katic@gf.sum.ba
}

\begin{abstract}
Research shows that there is a significant resources waste in construction, and accordingly lagging in productivity behind the productivity of the global economy and industry in particular. There is also a small number of papers and studies on this waste. On the other hand, a higher productivity level requires small waste of material, energy and other inputs. Therefore, construction companies are deciding to introduce lean as one of the leading methods of waste reduction. This paper deals with the introduction of lean in construction companies in $\mathrm{BiH}$, currently at very low level. Bearing in mind that most construction companies in $\mathrm{BiH}$ are small, it concludes that introducing lean and thus reducing the resources waste and increasing productivity and competitiveness requires more information and particularly skills improvements.
\end{abstract}

Key words: construction industry, lean, waste, productivity

\section{Lean u građevinarstvu Bosne i Hercegovine}

Sažetak: Istraživanja pokazuju da postoje značajni gubici resursa u građevinarstvu te sukladno tome zaostajanje u produktivnosti za globalnom ekonomijom i industrijom posebice. Također, mali je broj radova i studija o tim gubicima. S druge strane, veći stupanj produktivnosti iziskuje manje gubitke materijala, energije i ostalih inputa. Stoga se građevinska poduzeća odlučuju na uvođenje leana kao jednog od vodećih metoda smanjivanja gubitaka. Ovaj rad se bavi sagledavanjem uvođenja leana u građevinska poduzeća u $\mathrm{BiH}$, koje je trenutno na niskoj razini. Zaključuje, imajući u vidu da je većina građevinskih poduzeća u BiH mala, da uvođenje leana i tim putem smanjivanja rasipanja resursa te povećanja produktivnosti i konkurentnosti traži znatno bolju informiranost i posebice veću naobrazbu.

Ključne riječi: građevinarstvo, lean, gubici, produktivnost

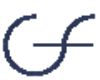




\section{INTRODUCTION}

Taiichi Ohno (1988), chief engineer in Toyota, identified seven types of waste within Toyota's production system (TPS): (i) overproduction, (ii) waiting, (iii) unnecessary transportation, (iv) overprocessing, ( $\mathrm{v}$ ) excess inventory, (vi) unnecessary movements and (vii) defects (repairing what has already been made), sometimes referred to as T-I-M W-O-O-D-(S) (acronym for the seven wastes concerned: Transportation - Inventory - Movement - Waiting Overproduction - Overprocessing - Defects - (Skills)). Namely, the eighth type of waste was later added - unused potential of employees.

For easier understanding, the wastes are usually grouped into two groups: (a) material flow (which includes the first five types of waste, or wastes (i-v)) and (b) labor (wastes vi-vii).

Various studies have found that waste represents a large percentage of costs in construction companies regardless of how it is defined and measured - as excess material consumed, rework, repairs, unproductive use of working time, etc. (Formoso, Bølviken and Dietz 2020).

In order to eliminate losses, construction companies decide, among other things, to introduce lean, or to maximize productivity (converting inputs into outputs) while reducing waste and time.

Compared to traditional financial indicators, some waste matrices (e.g. material wastes, non-value-adding time) are more effective to support process management as they allow operational problems to be better identified and generate information that is more meaningful to the workforce, creating thus conditions to more strongly implement decentralized control and thus increase productivity and efficiency.

Based on a review of a number of studies, Formoso, Bølviken and Dietz (2020) conclude that there are five categories of waste in construction compared to the seven in industry: (i) making-do wastes, (ii) work-in-progress (iii) unfinished work, (iv) waste due to transportation and (v) quality deviations waste

In some cases, making-do wastes can be large. They result from a failure to provide access and/or working area, to provide the necessary infrastructure (water, power supply, etc.), adequate protection, and equipment and tools. Simply put, the main reasons for making-do waste are ineffectiveness in providing adequate workspace, infrastructure, in planning and controlling the workspace and lack of information related to work tasks (Formoso, Bølviken and Dietz, 2020).

Several studies have established that work-in-progress losses are very high for several reasons: making-do, lack of synchronization between crews and poor logistics management of prefabricated building systems (Formoso, Bølviken and Dietz, 2020).

Wastes due to unfinished work occur because small works are usually neglected in activity planning meetings and because much of the work on construction sites is performed informally and therefore this work is not included in work plans. These small work packages usually have a large share in non-value-adding activities (Formoso, Bølviken and Dietz, 2020).

Transportation losses are related to the transportation of material waste, waiting for transportation, formation of inventories and accidents that occur in the process. The connection between transportation waste and making-do waste, such as failure to provide a scaffold on time, is very significant (Formoso et al., 2017; ; Pérez and Costa, 2018).

Losses due to quality deviations are characterized by high variability, poor deviation detection (e.g. due to the long period from detection to correction) and insufficient compliance with customer requirements. Quality deviations can result in customer complaints, rework, etc. (Formoso et al., 2017; Formoso, Bølviken and Dietz, 2020).

Although a comprehensive literature indicates that the amount of waste in the construction industry is quite high, the number of papers and studies on this waste is small. 
Arapović, A., Domljan, I., Katić, D.

Lean in Construction in Bosnia and Herzegovina

Hence the interest of the authors of this paper to analyze the application and role of lean in construction companies in Bosnia and Herzegovina $(\mathrm{BiH})$ with the purpose of reducing losses.

\section{LEAN IN CONSTRUCTION}

Productivity in construction has decreased by more than $20 \%$ over the last 40 years while at the same time industrial productivity has doubled (Zegarra and Alarcón 2019; Erthal and Marques, 2020; Domljan and Domljan, 2020).

Taking a global view, labor productivity in construction grew by $1 \%$ per year over the last 20 years. At the same time, the labor productivity of the world economy grew at a rate of $2.8 \%$ per year, and of industry at a rate of $3.6 \%$ per year, which clearly shows the lagging of construction (Barbosa et al., 2017).

According to the MGI Digitization Index, construction is one of the least digitized sectors in the world. It is the second last in the USA and the last in Europe in terms of digitization (Barbosa et al., 2017).

Productivity means converting inputs into outputs and is of crucial importance for the competitiveness and profitability of a company. Namely, construction companies can build similar structures, but those that use fewer resources have a competitive advantage. A high degree of productivity implies very small losses of material, energy or other inputs.

Widely known is Deming's observation, which became known as the $85 \%$ (later $94 \%$ ) Deming rule, according to which $85 \%(94 \%)$ of problems lie in the systems, processes, structures and practices of the organization while the remaining 15\% (6\%) are related to factors outside the system and it is the responsibility of management to improve this.

Two new approaches and technologies, which have been developing since the 1990s, have a particular importance for introduction into construction in order to increase productivity and decrease waste: BIM (Building Information Modeling) and Lean Construction (LC) (Dave et al., 2016; Sarhan et al., 2017; Tezel et al., 2020).

Some researchers believe that construction should be like industry when implementing lean, and that construction should therefore have a greater degree of industrialization and standardization. Others argue that the use of lean in construction is not a simple and direct copying of lean from industry, and believe that it is necessary to find new ways of project management, those that best fit the specifics of construction, to maximize value and minimize waste of resources (Meng, 2019).

Anyway, there is not a single definition of lean. Some believe it is not needed in the first place. Undoubtedly, it can be said that there are diverse views on the nature, scope and significance of lean. Based on surveys conducted among researchers, it could also be said that lean is a practical collection of theories, principles, axioms, techniques and ways of thinking that together and severally can help individuals and teams improve the processes and systems within which they work (Mossman, 2018).

The term lean construction has its roots in the International Group for Lean Construction (IGLC), more precisely from the first meeting of the group held in 1993. The term was created by adopting the thinking developed in the Japanese automotive industry and adapting it into the construction industry, and it implies better meeting client expectations while using "less of everything".

The key principles of lean thinking are: (i) eliminate waste and variability, (ii) very precisely establish the values wanted by the ultimate customer, (iii) clearly identify the process that delivers what the customer values (the value stream) and eliminate redundant, or non-value-adding steps, (iv) make the remaining value-adding steps flow without interruption by managing the interfaces between these steps, (v) let the customer pull, do not 
make anything until necessary, and then do it quickly and (vi) pursue perfection by continuous improvement.

This thinking is operationalized through various techniques such as the Last Planner System, stepwise improvement system (kaizen), visual management, value stream mapping (VSM), just-in-time, JIT logistics etc. (Tezel et al., 2020).

Having in mind the organizational structure of the construction sector (especially in $\mathrm{BiH}$, which has only nine large companies), it should be noted that the study of lean in SMEs (small and medium-sized enterprises) has attracted little attention from researchers, as evident from the negligible number of research papers.

Tezel et al. (2018) believe that the main barriers to implementing lean in SMEs are: (i) finances that do not allow significant investments in innovation, (ii) uncertainty of these companies that large clients will support them enough as partners in lean, (iii) non-integration into the collaborative value chain, so that SMEs do not realize any major benefits from lean, (iv) general skepticism that SMEs can achieve mutual benefits from collaboration and similar initiatives, and ( $v$ ) lack of customer support and/or imperative to help develop lean within their small suppliers.

The research interest in SMEs lean has increased since 2010. A noticeable trend is that construction SMEs are much more interested in lean than design SMEs (construction vs. design) (Tezel et al., 2018).

The current literature focuses on implementation of lean techniques through pilot projects and case studies as the main research methods. Therefore, there is not enough theoretical research on lean, and consequently no consideration of organizational issues, training, governance, etc. in the implementation of lean. In particular, there is a lack of papers focused on lean construction training and diffusion mechanisms within SMEs (Tezel et al., 2018; Gupta, S., Ahmadi, M.A. and Kumar, L., 2020).

\section{DESIGN AND RESEARCH RESULTS}

The study on the presence of lean in construction companies in $\mathrm{BiH}$ was conducted by surveying graduates of the Faculty of Civil Engineering, University of Mostar, masters of science in civil engineering who completed their studies in the period from 2010 to 2020. According to the list on the website of the Faculty of Civil Engineering, 419 students graduated during that period. Since their contact information was not available, 150 of them were reached via social networks (Facebook, Instagram) and questionnaires were sent to them.

The survey, which was anonymous, was conducted in June 2021. using the commercial survey software Kwiksurveys designed to create online surveys, questionnaires and quizzes.

The statistical method of data processing, the method of descriptive statistics (arithmetic mean, standard deviation, response frequencies) was used.

The survey was responded by 66 masters of science in civil engineering: 40 employed in construction companies in $\mathrm{BiH}, 22$ from Croatia and others from other countries, where this paper considers only the responses from $\mathrm{BiH}$.

Approximately half (52\%) of respondents work in small enterprises ( $<49$ employees), a third $(33 \%)$ in medium-sized enterprises (50-249 employees) and the rest $(15 \%)$ in large enterprises (>250 employees). The standard deviation is 6.13 .

The largest number of respondents (42\%) work in construction, followed by $33 \%$ in design, and $5 \%$ in investment, project management and professional supervision/control. The category others accounts for $10 \%$. None of the respondents is employed in the field of providing consulting services. The standard deviation is 6.06 . 
Those who work in construction companies most often work on building construction projects $(40 \%)$, followed by civil engineering projects $(25 \%)$, and other projects $(22 \%)$ and specific industrial plants/facilities (13\%). The standard deviation is 3.24.

Twenty-sever percent of respondents work in the positions of site/works/construction manager and designer/reviewer, $10 \%$ of respondents in the position of project manager, and $5 \%$ of respondents in the position of supervising engineer, $3 \%$ in the position of assistant site manager/manager and in the position of company management member. Other positions account for $25 \%$. None of the respondents was employed as a lean construction expert/consultant. The standard deviation is 4.53.

Most respondents $(75 \%)$ have up to three years of work experience, $22 \%$ of respondents have three to five years, and the remaining $3 \%$ have five to ten years of work experience. The standard deviation is 11.51 .

Detailed results related to the survey questions about the extent to which the respondents know and apply the six principles of lean thinking, and summary results regarding the knowledge and implementation of lean tools/techniques are given below.

\subsection{Lean thinking}

Forty-four percent of respondents are not familiar with the possibility of systematic elimination of resource losses during the work process, and therefore do not apply the principle, $31 \%$ of respondents are partially familiar with the theoretical bases, but do not apply the principle in practice, $14 \%$ are familiar with the principle and started its application in practice while $11 \%$ are familiar with the principle and apply it in practice (Figure 1).

\section{Elimination of losses during the work process}

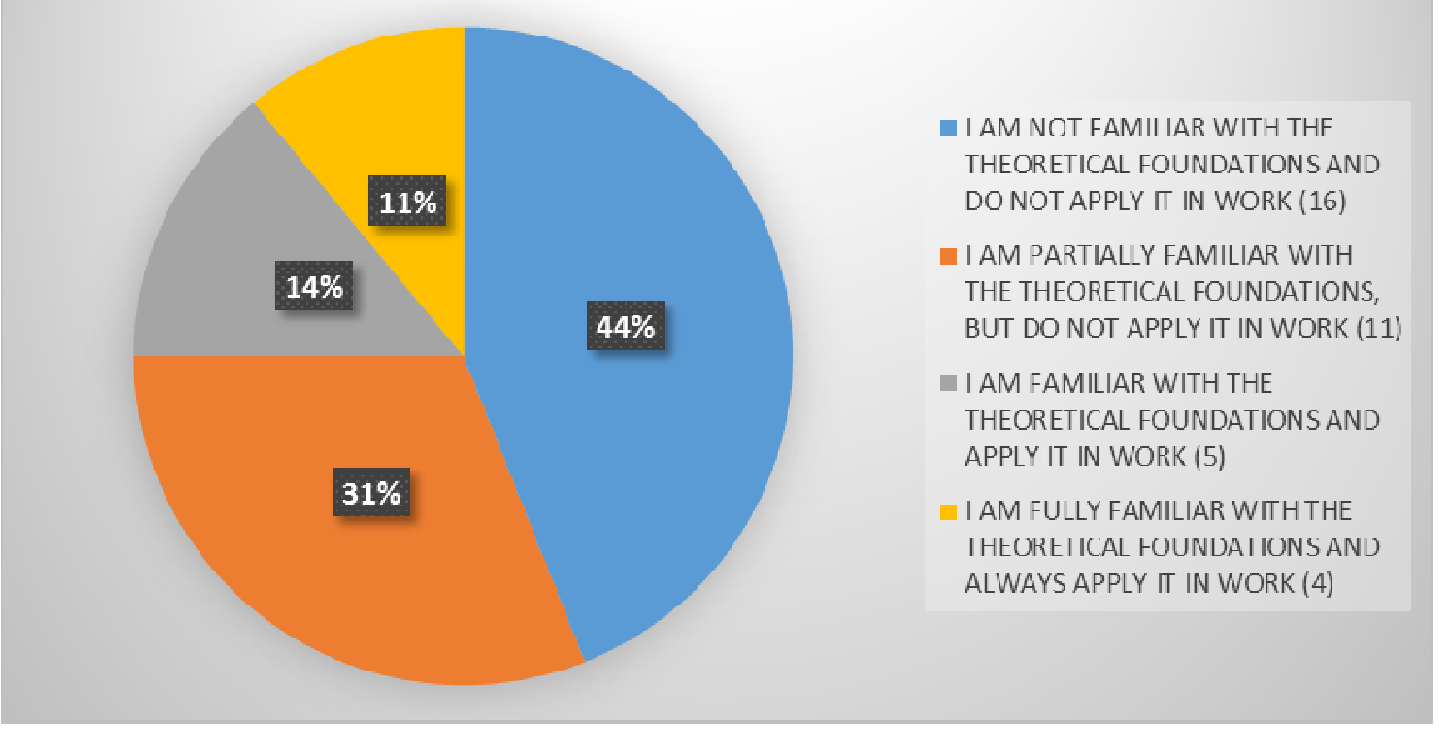

Figure 1. Elimination of losses during the work process 


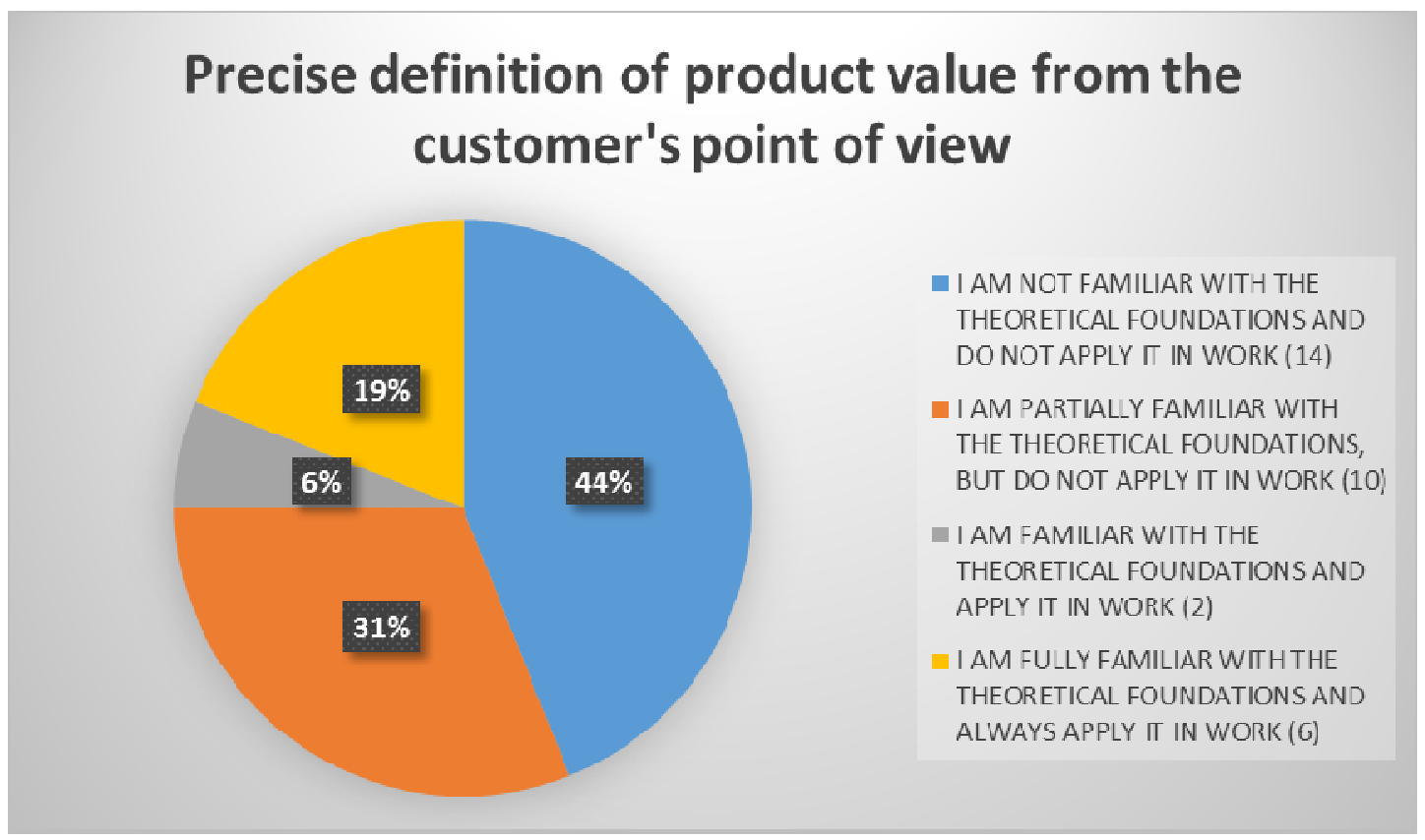

Figure 2. Precise definition of product value from the customer's point of view

When defining product value from the customer 's point of view, $44 \%$ of respondents are not familiar, $31 \%$ are partially familiar, $6 \%$ are fully familiar and $19 \%$ are fully familiar with the principle and apply it in practice (Figure 2).

Fifty-two percent of respondents are not familiar with the value stream for a particular type of product, $24 \%$ are partially familiar but do not apply it in practice, $9 \%$ are familiar and started applying it, while $15 \%$ are fully familiar with the principle and apply it in practice, as shown in Figure 3.

\section{Identification of the value stream for a particular type of product}

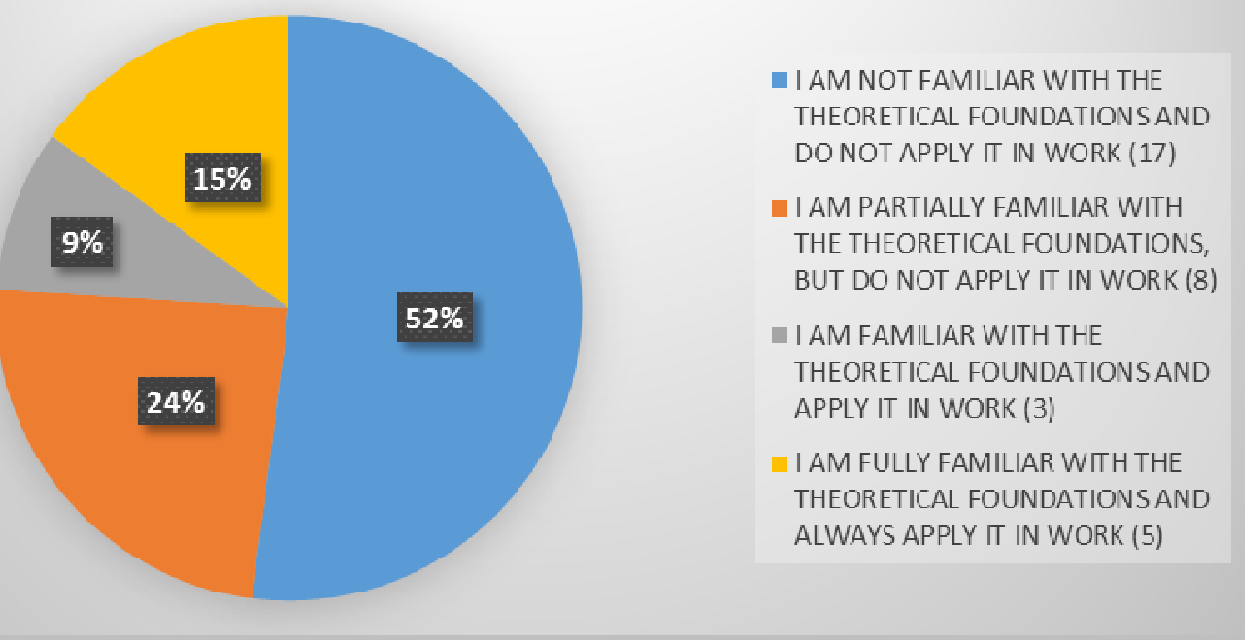

Figure 3. Value stream identification 


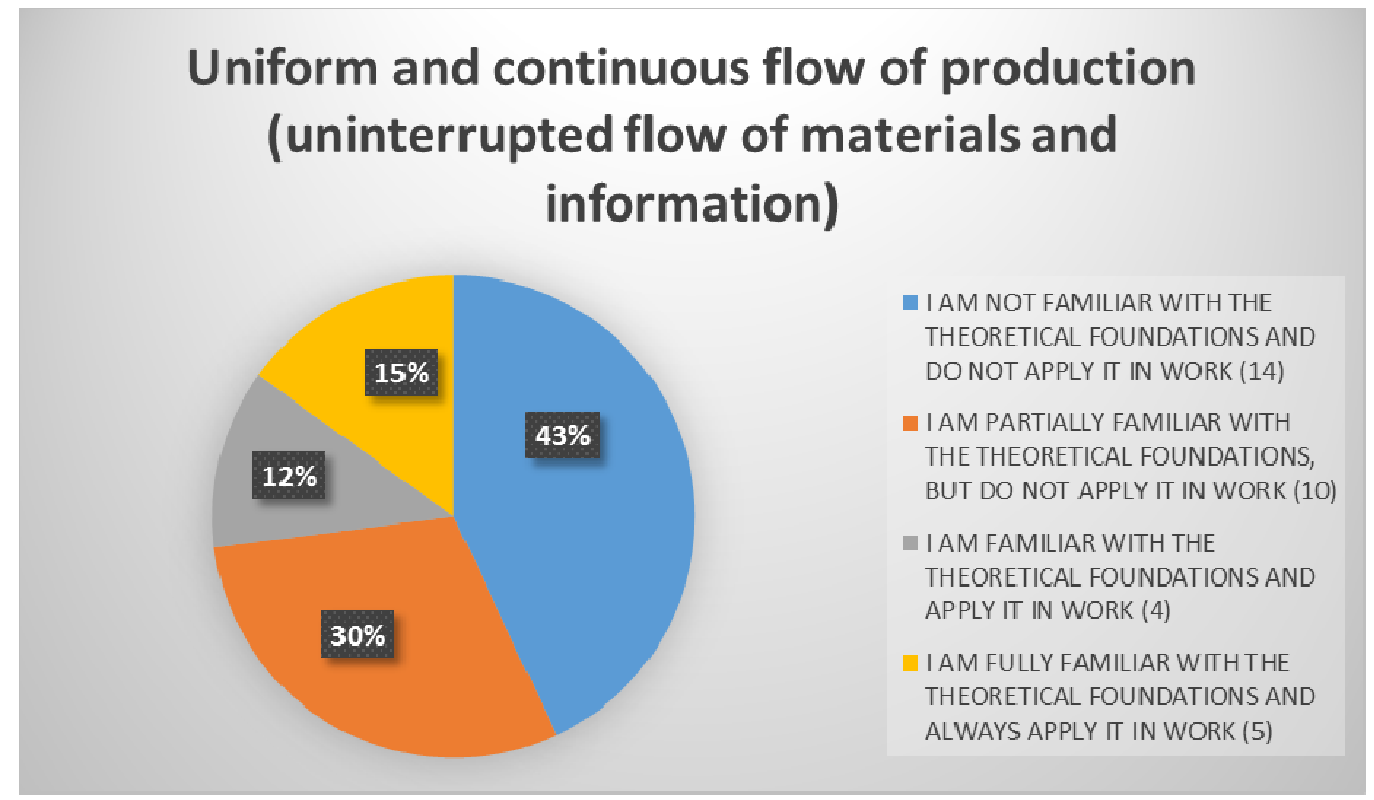

Figure 4. Uniform and continuous flow of production

Forty-three percent of respondents are not familiar with the principle of uniform and continuous flow of production (uninterrupted flow of materials and information), $30 \%$ are partially familiar but do not apply it, $12 \%$ are familiar with the principle and have started its application, while $15 \%$ are fully familiar with the principle and apply it in practice, as shown in Figure 4.

Forty percent of respondents are not familiar with the pull of product throughout the production process, $39 \%$ are partially familiar but do not apply the principle, $9 \%$ are familiar with the principle and started applying it, while $12 \%$ of respondents are fully familiar with the principle and constantly apply it in practice (Figure 5).

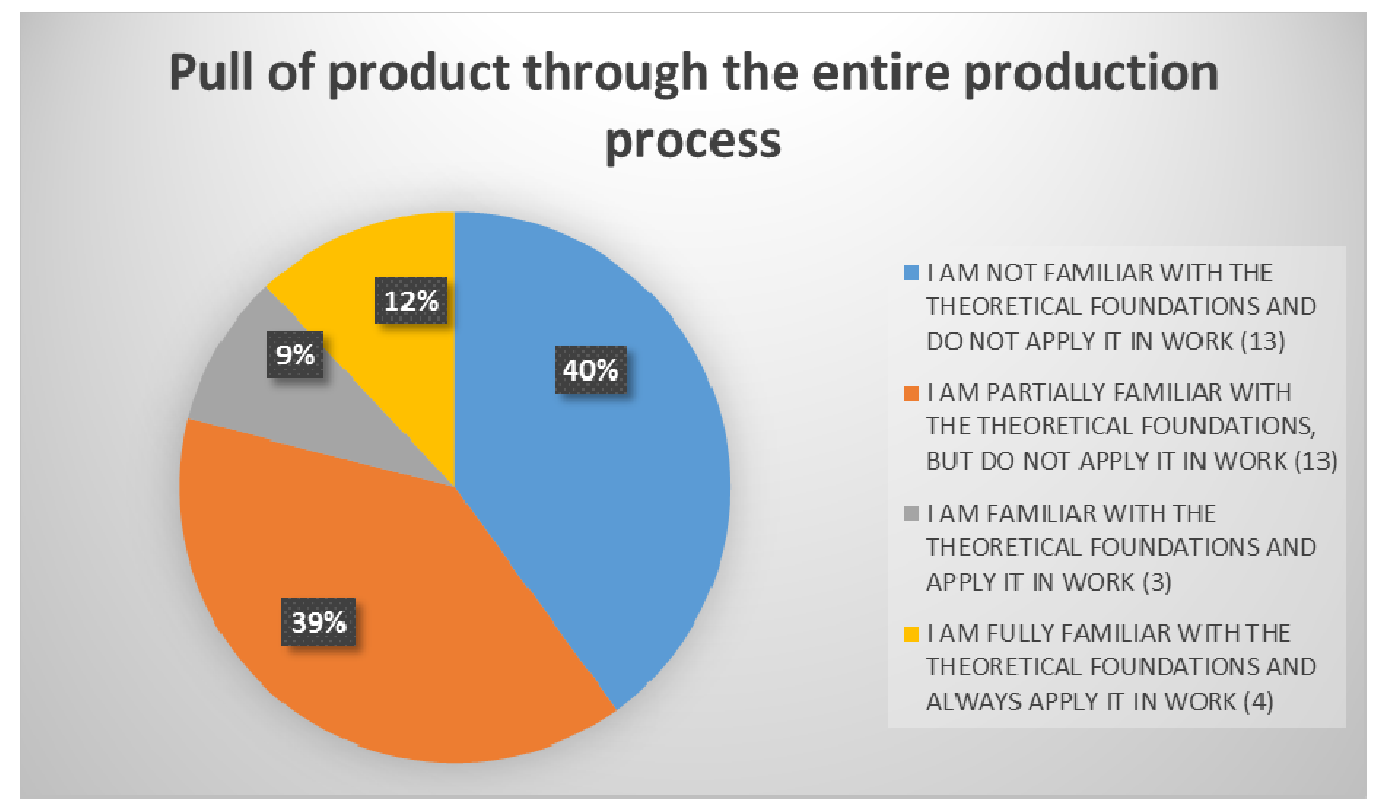

Figure 5. Pull of product through the entire production process 


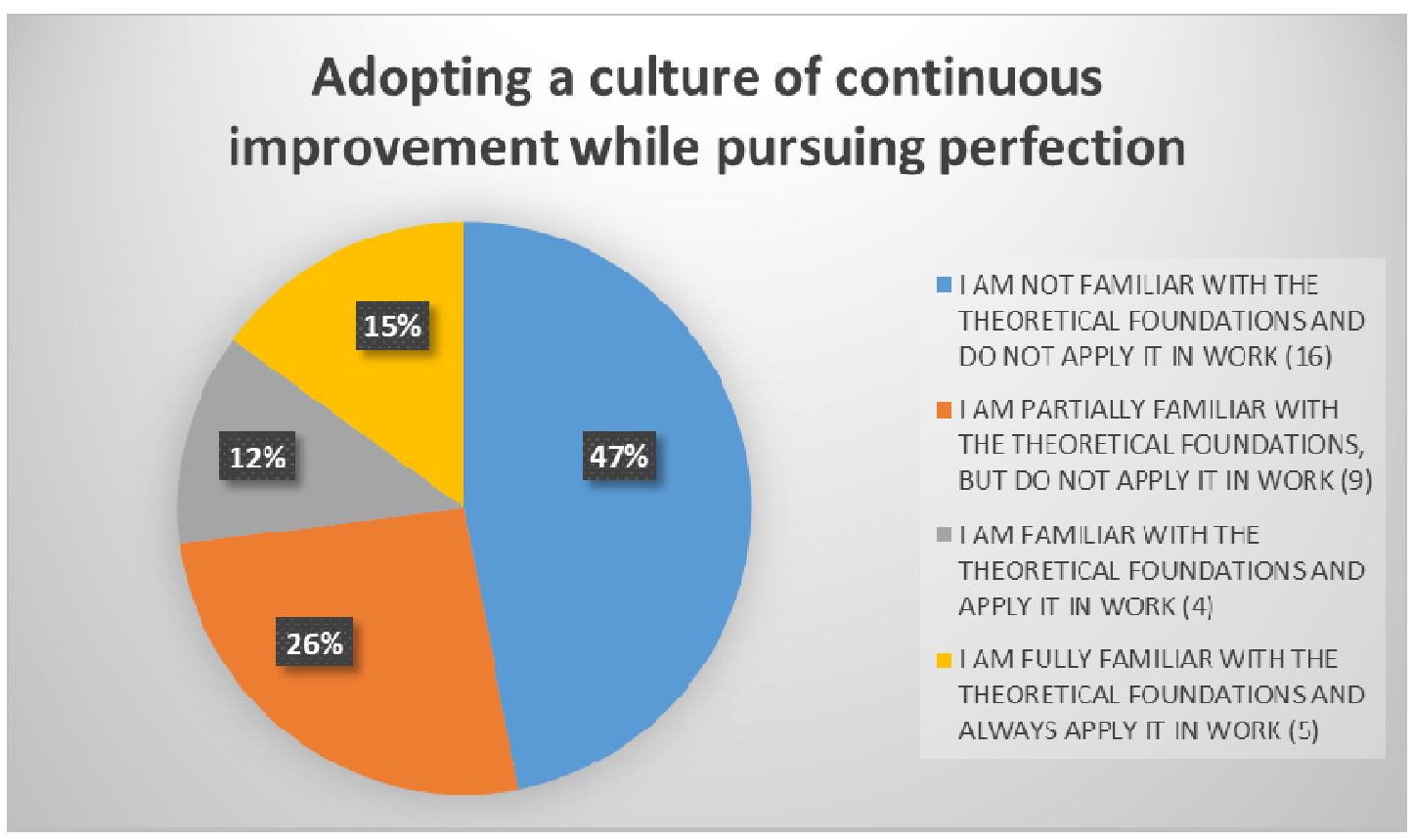

Figure 6. Adopting a culture of continuous improvement

As shown in Figure $6,47 \%$ of respondents are not familiar with the need to adopt a culture of continuous improvement while pursuing perfection, $26 \%$ are partially familiar but do not adopt the principle, $12 \%$ are familiar and started its adoption, while $15 \%$ are fully familiar with the principle and apply it in practice.

\subsection{Lean operating mode}

People, knowledge and organization are interconnected and intertwined concepts. People, as individuals or a collective, have knowledge and use it to organize activities. Understanding the lean way of working requires knowledge not only of the theory of production but also of the theory of organization.

The biggest challenge facing construction companies when implementing lean is to transform the existing organization into one that strives for continuous improvement. If the key to lean thinking or production theory is in understanding and designing production processes, it is undeniable that these processes depend on people.

The Last Planner System expresses the balance between people and production processes in construction. Moving from a stable industrial production line to a dynamic project organization requires a shift of focus from reducing inventory, which is key to Toyota's manufacturing system, to increasing planning responsibility while maintaining an emphasis on time. A wide range of visual management tools, from flow value mapping to kanban and andon, among others, have also been designed with the importance of communication in mind for process management.

The literature on the difficulties switching to lean, especially to the last planner system, is highly developed. Moreover, structural patterns have been established in the resistance to change to lean, based on inadequate training, resistance to training, inadequate choice of lean tools, lack of understanding of lean (Rooke, 2020).

With regard to the lean operation mode, the respondents were asked ten questions in this research: 1. continuously identifying and assessing problems, developing and 
implementing solutions and measuring the achieved results; 2 . using several types of digital technologies, especially construction information technologies (for example BIM (Building Information Modeling)) aimed at facilitating the flow of information and developing the construction system object prototype; 3 . encouraging continuous measurement, analysis and improvement based on the resources used, time required, quality requirements of the client and other characteristics; 4. using user-friendly digital views to increase process transparency and facilitate control of the work and flow of information; 5. planning of work so that the completed activities immediately pull the next one for the purpose of reducing losses, or producing only at the request of the customer in order to keep inventories as low as possible; 6 . implementing classification control, establishing order, standardization, cleaning and self-discipline during work; 7. continuously implementing the plan - do - check - act process during the work; 8 . maintaining regular communication and meetings, joint planning and increasing the level of trust and commitment among team members; 9. planning work based on the time required to deliver a particular process - takt, which is repetitive and 10 . managing the supply of construction materials and equipment with the purpose of delivering them just before installation, avoiding excessive on-site storage.

According to summarized and averaged answers, $36 \%$ of respondents are not familiar with the lean operation mode according to lean construction tools/techniques, $22 \%$ are partially familiar but do not apply it in their work, $24 \%$ are partially familiar and started using it while $18 \%$ are fully familiar with the operation mode according to lean construction tools/techniques and apply it in their work, as shown in Figure 7.

\section{Way of work according to Lean construction tools/techniques}

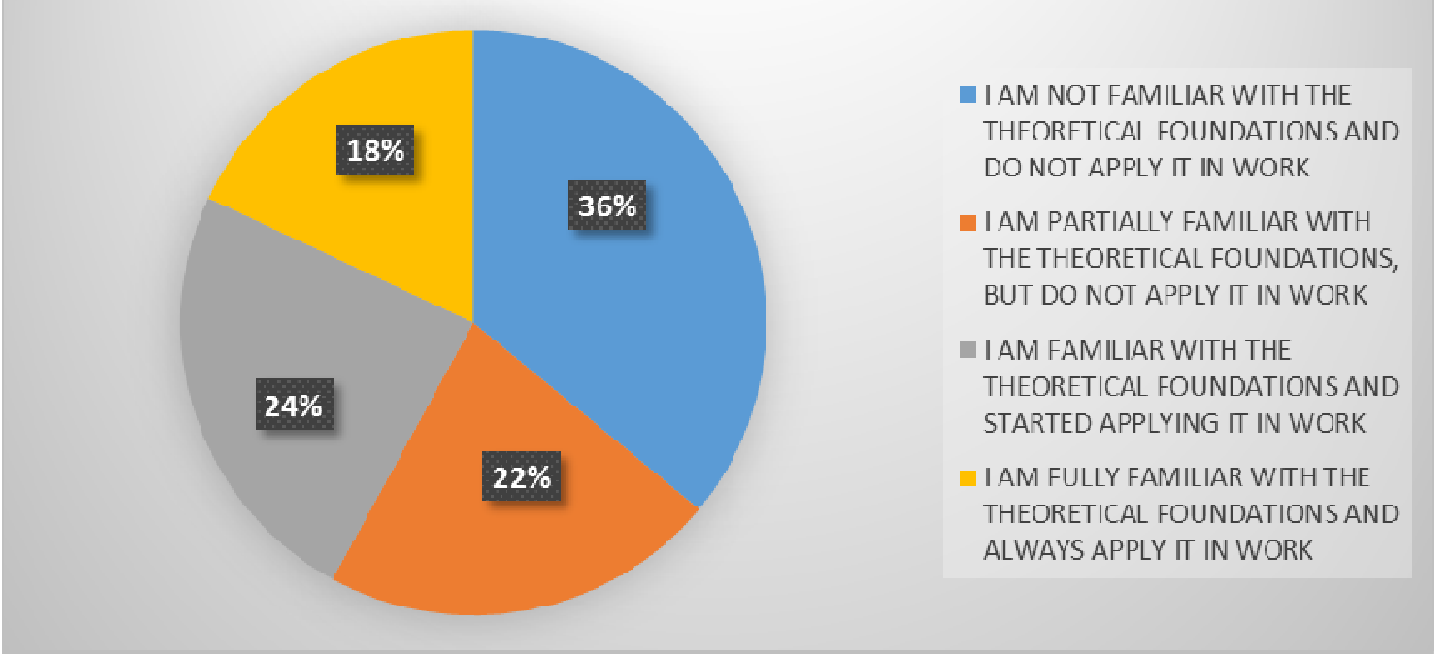

Figure 7. Way of work according to lean 


\subsection{Using lean tools/techniques}

Typical tools used in lean are: (i) the $5 S$ process $^{1}$; (ii) mistake proofing - poka yoke; (iii) current reality trees; (iv) evaporating cloud, EC; called also conflict resolution diagram; (v) future reality diagram; (vi) inventory turnover rate; (vii) just-in-time (JIT) theories; (viii) kaizen $^{2}$; (ix) kanban ${ }^{3}$; (x) lean metrics ${ }^{4}$; (xi) one-piece flow; (xii) overall equipment effectiveness (OEE) ; (xiii) prerequisite tree; (xiv) process route table; (xv) quick changeover; (xvii) standard rate of work; (xvii) theory of constraints; (xviii) total productive maintenance; (xviii) Toyota production system; ( $x x$ ) transition tree; (xxi) value added to non-value added lead time ratio; (xxii) value stream mapping; (xxiii) value stream costing; (xxiv) visual management or controls; and (xxv) workflow diagram (Vanzant Stern, 2020).

Regarding the use of lean construction tools/techniques, respondents were asked ten questions related to the use of: 1. last planner system, 2. Total Quality Management (TQM), 3. just-in-time (JIT), 4. pull kanban system, 5. increased visualization, 6. takt time planning, 7. continuous improvement, 8. Five S's, 9. information technologies to support lean construction deployments and 10. problem solving process - PDCA cycle (Plan - Do - Check - Act Cycle).

According to summarized and average responses (Figure 8 ), $54 \%$ of respondents are not familiar with and consequently do not apply lean construction tools/techniques, $27 \%$ are partially familiar but do not apply them in the work, $10 \%$ are partially familiar and started using them while $9 \%$ of them are fully familiar with the techniques concerned and apply them in their work.

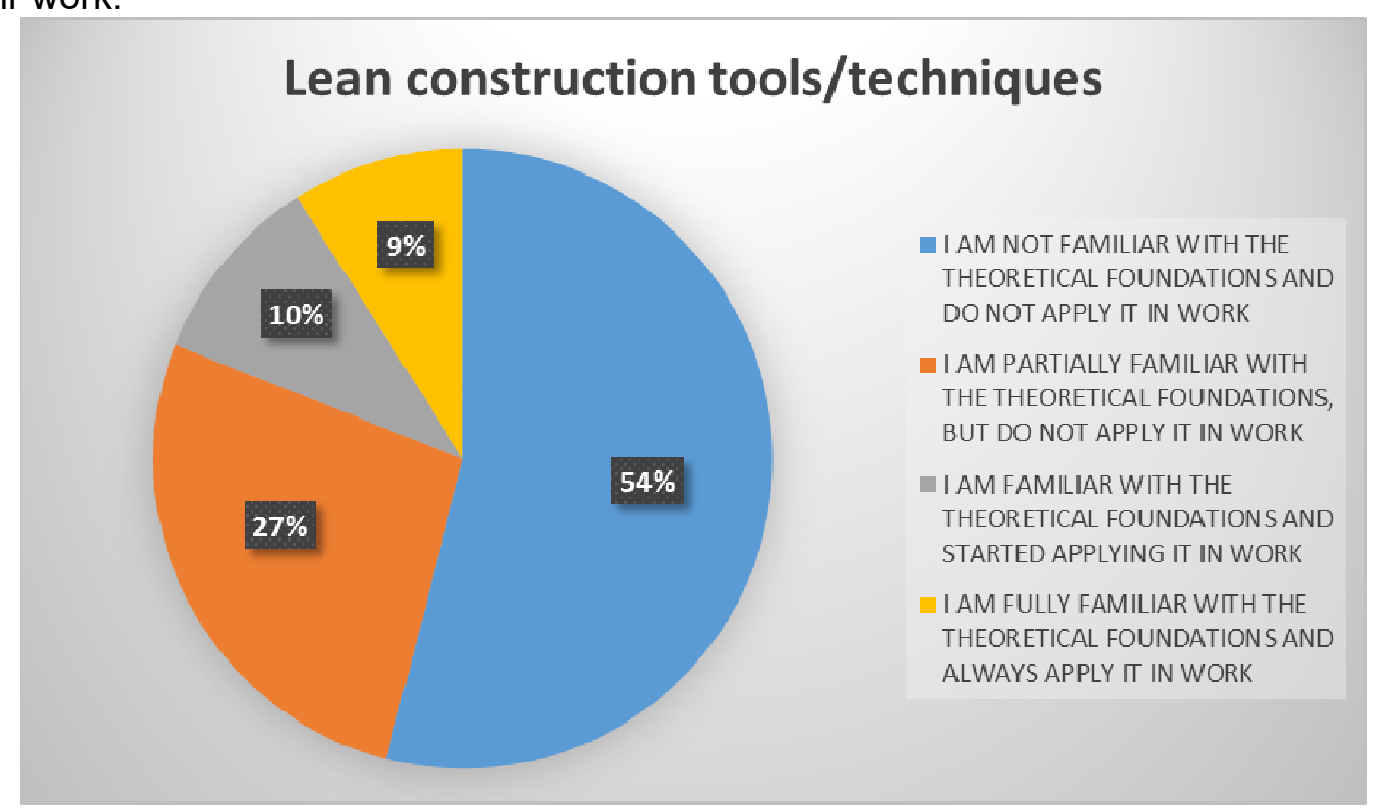

Figure 8. Lean construction tools/techniques

\footnotetext{
1 Process 5S, according to the translation from Japanese to English: Seiri-Organization, Seiton-Neatness, SeisoCleaning, Seiketsu-Standardized Cleaning, Shitsuke-Discipline.

2 Kaizen is translated from Japanese as kai-change and zen-for the better or as continuous improvement. Teamwork results in gradual but also continuous improvements in productivity because numerous ideas are presented, daily procedures are improved, employees become interested, which makes the work self-fulfilling, less boring and more secure.

${ }^{3}$ Kanban is translated from Japanese as a visual board. It shows tabularly (i) what needs to be done, (ii) what is being done and (iii) what has been done in real time, indicating bottlenecks in implementation.

${ }^{4}$ Lean metrics include: 1 . cycle time, or time from the beginning to the end of the production/process, and the like; 2. throughput rate, which shows the rate of progress of the activity, 3. takt time, or the time required to produce a unit in a sequence, 4 . cumulative flow, and 5 . root cause analysis.

${ }^{5}$ When the overall equipment effectiveness (OEE) is $100 \%$ it means that only good parts are produced $(100 \%$ quality), at a maximum rate (100\% performance) and with no down time (100\% availability).
} 
Arapović, A., Domljan, I., Katić, D.

Lean in Construction in Bosnia and Herzegovina

\section{CONCLUSION}

Research indicates low productivity of construction companies, or insufficiently efficient conversion of inputs into outputs, because this process is accompanied by excessive waste. In order to reduce waste, construction companies, among other things, are turning to lean or a system of gradual but continuous improvement of production flows.

Numerous studies also indicate that there are structural problems of the transition of construction companies to lean caused at the root by insufficient information and inadequate education.

This research confirmed that the majority of respondents in construction companies in Bosnia and Herzegovina are not familiar with lean, i.e. they are not familiar with the theoretical foundations of lean, so they do not implement lean thinking, lean mode of operation and lean tools in their activities.

Most of the respondents encountered the concept of lean for the first time through this survey, while the rest became familiar with it through formal (studies) and informal education (courses, extracurricular reading, webinars, etc.).

Since there is no research on lean in $\mathrm{BiH}$ construction, this paper will certainly serve as a reference in future, much-needed research.

\section{REFERENCES}

1. Barbosa, F. et al.: Reinventing Construction: A Route To Higher Productivity, McKinsey Global Institute McKinsey Global Institute I McKinsey \& Company, 2017.

2. Domljan V., Domljan I.: Efficiency of the Bosnian-Herzegovinian Economy. In: Karabegović I. (eds) New Technologies, Development and Application II. NT 2019. Lecture Notes in Networks and Systems, Vol. 76. Springer, Cham, 2020. DOI:10.1007/978-3-03018072-0 40

2. Erthal, A. and Marques, L.: Organisational culture in lean construction: managing paradoxes and dilemmas, Production Planning \& Control, Latest article published online 15 Nov 2020. DOI:10.1080/09537287.2020.1843728.

3. Formoso, C. T., Bølviken T. and Dietz Viana.: Understanding waste in construction, In: Tzortzopoulos, P., Kagioglou, M. and Koskela, L. (Eds), Lean Construction: Core Concepts and New Frontiers. New York and London: Routledge, 2020.

4. Formoso, C.T., Sommer, L., Koskela, L., Isatto, E.L.: The identification and analysis of making-do waste: Insights from two Brazilian construction sites, Ambiente Construído, 17(3), 2017, pp. 183-197.

5. Gupta, S., Ahmadi, M. A. and Kumar, L.: Identification of the Barriers of Lean Construction Implementation in Construction Projects - A Review, International Journal of Innovative Research in Computer Science \& Technology (IJIRCST), Volume 8, Issue 3, May 2020, DOI:10.21276/ijircst.2020.8.3.27, Available at: www.ijircst.org

6. Meng, X.: Lean management in the context of construction supply chains, International Journal of Production Research, Volume 57, Issue 11, 2019,

DOI:10.1080/00207543.2019.1566659.

7. Mossman, A.: What is lean construction: another look, In: Pros. 26th Annual Conference of the International, Group for Lean Construction (IGLC), González, V.A. (ed.), Chennai, India, 2018, pp. 1240-1250. DOI:10.24928/2018/0309, Available at: www.iglc.net.

8. Ohno, T.: Toyota Production System: Beyond Large-Scale Production. Cambridge: Productivity Press, 1988. 
9. Pérez, C.T., Costa, D.B.: Developing a taxonomy of transportation waste in construction production processes, Built Environment Project and Asset Management, 2018, DOI:10.1108/BEPAM-04-2018-0062

10. Plenert, G., Plenert, J.: Strategic Excellence in the Architecture, Engineering, and Construction Industries - How AEC Firms Can Develop and Execute Strategy Using Lean Six Sigma. London: Routledge, 2018.

11. Rooke, J.: Lean Organisation, In: Tzortzopoulos, P., Kagioglou, M. and Koskela, L. (Eds) Lean Construction: Core Concepts and New Frontiers. New York and London: Routledge, 2020.

12. Tezel, A., Taggart, M., Koskela, L., Tzortzopoulos, P., Hanahoe, J. and Kelly, M.: Lean construction and BIM in small and medium-sized enterprises (SMEs) in construction: a systematic literature review, Can. J. Civ. Eng. 47, 2020, pp. 186-201, DOI:10.1139/cjce2018-0408.

13. Vanzant Stern, T.: Lean and Agile Project Management: How to Make Any Project Better, Faster, and More Cost Effective, Second Edition. New York and London: Routledge, 2020.

14. Zegarra, O., Alarcón, L. F.: Coordination of Teams, Meetings, and Managerial Processes in Construction Projects: Using a Lean and Complex Adaptive Mechanism. Production Planning \& Control, 30 (9), 2019, pp. 736-763, DOI:10.1080/09537287.2019.1578905. 